\title{
Analysis on Influence of Bank Specific Factors on Non-Performing Loans among Commercial Banks in Kenya
}

\author{
William Abungu Onyango ${ }^{1}$, Clement O. Olando ${ }^{2, *}$ \\ ${ }^{1}$ Accounting and Finance Department, Mount Kenya University, Kenya \\ ${ }^{2}$ School of Business and Economics, Mount Kenya University, Kenya
}

Received July 29, 2019; Revised January 6, 2020; Accepted January 13, 2020

Copyright $\subseteq 2020$ by authors, all rights reserved. Authors agree that this article remains permanently open access under the terms of the Creative Commons Attribution License 4.0 International License

\begin{abstract}
Occurrences of banking financial crises as well as commercial bank failures in Kenya are usually associated with elevations in accumulation of non-performing loans. This study therefore analyzed the influence of bank specific factors on the level of non-performing loans among the commercial banks in Kenya. This study employed descriptive research design using the forty-three (43) currently licensed commercial banks as its target population. Using census, the study collected secondary data from the previous year's financials statement and other financial reports for period covering 2012 to 2016. Quantitative analysis was used to produce descriptive statistics and inferential analysis carried out to predict a study model for estimating Non-Performing Loans in terms of banks related factors. The study revealed that the average level of NPLs among Kenyan commercial banks is higher than the threshold of 5\% signaling a serious NPLs problem amongst commercial banks in the country. The study concludes that at $5 \%$ level of significance; interest rate spread has positive significant influence on NPLs; operating efficiency is directly proportional to non-performing loans and it has a moderate positive significant influence on the non-performing loans among commercial banks in Kenya; liquidity ratio has a negatively low significant relationship with non-performing loans.; and return on assets has a negative significant influence on NPLs among commercial banks in Kenya. ROA has a negative impact.
\end{abstract}

Keywords Banks Operating Efficiency, Bank Specific Factors, Commercial Banks, Interest Rate Spread, Liquidity Ratio, Non-Performing Loans, Return on Average Assets

\section{Introduction}

\subsection{Background to the Study}

World over, the banking industry, being amongst the highly recognized sectors for spurring economic growth of country, is a very important platform for enhancing collection of money from those people regarded as having excess (lenders) and availing that money for access to those in need of it; that is the borrowers (Ghasemi \& Rostami, 2016; Musau, 2014). Thus, this industry plays the intermediation role of collecting surplus money and lending it for investment. Efficient financial intermediation of lending credit to borrowers, by banks, is one means of contribution to the growth of a country's economy (Asmare. 2014). Commercial banks, which act as one of the key financial intermediaries and a main source of funding, dominate the banking industry in this process of funds mobilization (Heimdal \& Solberg, 2015). They take the lion's share of funds intermediation (lending process) within the industry, significantly contributing to economic development of a country through financial mobilization of investible resources.

The loan assets are the most dominant asset of the investible resources of commercial banks as account for approximately between $55 \%$ and $75 \%$ of the banks' total assets, representing the banks greater risk exposure (Musau, 2014). Most recently, due to increasingly uncontrolled non-performing loan (NPL) assets, commercial banks have started become relatively very cautious in their course of advancing loans (Gezu, 2014). According to Iftikhar (2015), accumulations of NPLs were precursor to the most recent worldwide financial crisis. In fact, NPL significantly contributed to the 2007/2008 global crisis in the financial 
issues that originated form the United States (US), characterized by very large increases in NPLs and deterioration of loan performance across countries (Muriithi, 2013). The worldwide uncontrolled growth of NPL is becoming a major reason most countries continue to become poor economic and socioeconomic environments, further worsening crisis effects (Mingaleva, Zhumabayeva \& Karimbayeva, 2014). Globally, the crisis effect of NPL has shown a consistent pattern of NPL in both before and after the global financial crisis (Chimkono, Muturi \& Njeru, 2016). In the European countries, the NPLs are widespread up to a ratio of about $5.1 \%$ of total loans (Navaretti, Calzolari \& Pozzolo, 2017) where Italy had the largest concentration of NPL, Greece and the highest NPL ratios of $46 \%$ and the Sweden had the lowest NPL ratios at 1\%. Countries in East Asia as well as those in Sub Saharan African also faced crisis in their financial and banking sectors that was preceded by accumulation of NPLs (Vatansever \& Hepsen, 2013). In the African countries, poor banking credit assessment, ineffective loan monitoring, weak conditions of lending and poor terms of credit, high levels of lending, weak bank institutional capacity and compromised banking integrity have been found to lead to incidences of NPLs (Gezu, 2014). Kenya is no exception since it has its fair share of banking challenges since 1980s, resulting in major failures in the banking industry due to increased NPLs levels (Musau. 2014). Muriithi (2013) postulates that the Kenya banking sector is facing crises due to massive accumulation of NPLs, an insinuation support by Karumba and Wafula (2012) who indicate that there is observed high default rate of bank loans amounting to an estimated $54 \%$ of bank total credit risk. This huge contribution of NPLs towards credit risk is significantly affecting bank performance, rendering credit risk being identified as the most challenging risk faced by banks while defaults rates have led to piling of NPLs in bank's balance sheet. Apparently, there is a wide increase in the NPLs amongst the Kenyan commercial banks (CBs), rising from a gross value of Ksh. 143 billion as of December 2015 to Ksh. 208 billion in December 2016 (Central Bank of Kenya [CBK], 2016), which translates to increase of $45.3 \%$ of NPLs among Kenyan CBs. In the same period, the gross NPLs to gross loans (GLs) ratio increased from $6.2 \%$ as of December 2015 to $9.2 \%$ in December 2016 from. Consequently, assets quality, in terms of net NPLs to GLs, deteriorated to $4.3 \%$ in December 2016 from 2.6\% in December 2015. The increasing levels of NPLs caused the bad debts charge to increase from a value of Ksh. 30.8 billion as at December 2015 reaching a maximum of Ksh. 42.4 billion as recorded in the final days of December 2016.

During the period of the study, Kenyan CBs registered increased NPLs as evidenced by Central Bank of Kenyan (2016) which reported the widely increasing accumulation of NPLs among Kenyan CBs with common financial crises amongst these banking institutions and empirical literature on commercial banks in the country (Atem, 2017; Gathaiya, 2017; Muchoki \& Were, 2016, Genga, 2016; Musau. 2014; Muriithi, 2013; Ongore \& Kusa, 2013). Empirical study by Gathaiya (2017) revealed that there is increasing accumulation of NPLs among Kenyan commercial banks which prompts financial crises among these financial institutions. Muchoki and Were (2016) found that these NPLs result into continued unhealthy operating environment within the banking sector leading to challenges including financial distress. As Genga (2016) indicates, some commercial banks in Kenya collapsed as a results of the NPLs' accumulation. The study by Musau (2014) revealed that CBs in Kenya have been experiencing banking problems since 1980s, culminating in major bank failures due to high levels of non-performing loans. The empirical study by Muriithi (2013) established that there was occurrence of banking crises in Kenya which is associated with a massive accumulation NPLs among CBs in Kenya. Muriithi (2013) further revealed that NPLs are also one of the major causes of the economic stagnation in the country as Ongore and Kusa (2013) added that increasing levels of NPLs are most likely capable of hindering the economic growth and impairing the economic efficiency in the country.

Since CBs are seeking to maximise their profits for their shareholders, they sometimes enlarge their interest rate spread (IRS), by advancing loans at higher rates of lending and lower deposit rates (Ghasemi \& Rostami, 2016; Irungu, 2013). However, sustained high interest rate spreads is an indication of an inefficient financial system and is attributable to retarded economic growth (Asmare. 2014). Further, serious liquidity problems with CBs are associated with poor loan collection capabilities, where ineffective loan management practices would most likely lead to high levels of NPLs in the Kenyan banking industry (Musau. 2014). Notably, NPLs represent the largest share of banks assets among the CBs. Abdeta (2015) posits that bad management hypothesis explains the causality of NPLs' as being a product of banks' operational efficiency. The hypothesis explains that poor operational efficiency is characterized by inefficient management of banking operations by managers. Abdeta (2015), citing the moral hazards, posits that NPLs are attributable to high loans to assets ratio which reflects low financial capital. On the extreme, Cucinelli (2015) postulates that when a commercial bank lowers its ratios of loans to deposits, that is LDR (loans to deposits ratio), this is interpreted to imply that the that banks dependent less on wholesale funding. Such as occurrence is an implication that the CB's asset growth is less constrained to the market. According to Shingjerji (2013), evidence from research in different countries shows that return on asset (ROA), affect the NPLs. For instance, the study by Vasiliki, Athanasios \& Athanasios (2014) revealed that ROA significantly affects NPLs among the banks in the Euro zone. Vasiliki et al. (2014) conclude ROA in terms of; asset utilization 
efficiency, and poor asset utilization results into higher bank NPLs as the relationship between ROA and NPLs is a positive significant one. Based on the argument by various authors and empirical studies, it is clear that growth of NPLs among CBs is significantly influenced by certain bank specific factors. As Mingaleva, Zhumabayeva and Karimbayeva (2014) put it, high levels of NPLs in a country are precursor to hindrance of recovery of that country's economy. Notably most empirical studies on bank specific factors influencing NPLs growth in the banking industry were conducted in the developed economies, implying it vague on whether the same factors affect the Kenyan CB sector. Therefore, there is need for adequate research of the relationship between banks specific factors and NPLs among the Kenyan CBs to clear the uncertainty and suggest appropriate measure for controlling levels of NPLs across the commercial banking sector in the country. This motivates the present study, which proposes that the level of NPLs among the Kenyan CBs is influenced by the bank specific factors.

\subsection{Statement of the Problem}

Statistics indicate that the collective Gross NPLs among Kenya CBs, as recorded in 2016, was a $45.3 \%$ increase (Central Bank of Kenyan [CBK], 2016). This increasing accumulation of NPLs is widely associated with bank failure and financial crises of commercial banks in Kenya. Further, continuously rolling NPLs would hinder the economic growth, impairing the economic efficiency in the country and undermines the confidence in the economy. It is therefore crucial to reveal the bank factors influencing NPL among CBs operating in Kenya so as to provide some guidance to banks on ways of improving the credit policies and also to policy makers with improved preventive measures and stress testing models appropriate to the local environment. Although numerous studies have been assessed and addressed the core factors leading to rising non-performing loans, most of these studies have embarked on revealing the factors affecting NPLs in developed countries. Generalization of the findings from studies to banks in developing economies such as commercial banks in Kenya is difficult. Further, most of the studies conducted locally, had emphasized much on the macroeconomic and customer specific factors. Thus, empirical literature on NPLs among Kenyan commercial banks as being influenced by bank specific factors in insignificant, a research gap the present study locked. Therefore, the present study established the bank specific factors influencing NPLs.

\subsection{Purposes of the Study}

The purpose of the present study was an analysis to establish whether; interest rate spread, banks operating efficiency, liquidity ratio and return on average assets significantly influences the levels of NPLs among Kenyan
CBs. The assessment established the relationship between each of the variables; interest rate spread, banks operating efficiency, liquidity ratio and return on average assets and NPLs among Kenyan CBs by testing a hypothesis and even the estimated model tested and analysed using Analysis of Variance (ANOVA).

\subsection{Objectives of the Study}

\subsubsection{General Objective}

The study's general objective was to assess the effect of bank specific factors on the level of non-performing loans among the commercial banks operating in Kenya.

\subsubsection{Specific Objectives}

The specific objectives of the study were:

i. To assess the influence of interest rate spread on non-performing loans among commercial banks in Kenya.

ii. To establish the influence of banks operating efficiency on non-performing loans among commercial banks in Kenya.

iii. To evaluate the influence of liquidity ratio on non-performing loans among commercial banks in Kenya.

iv. To determine the effects of return on average assets on non-performing loans among commercial banks in Kenya.

\subsection{Research Hypotheses}

The study tested the following hypotheses:

\section{Hypothesis 1}

$\mathrm{H}_{0}$ : Interest rate spread has no significant influence on non-performing loans among commercial banks in Kenya.

$\mathrm{H}_{1}$ : Interest rate spread has significant influence on non-performing loans among commercial banks in Kenya.

\section{Hypothesis 2}

$\mathrm{H}_{0}$ : Banks operating efficiency does not significantly influence the non-performing loans among commercial banks in Kenya.

$\mathrm{H}_{1}$ : Banks operating efficiency significantly influences the non-performing loans among commercial banks in Kenya.

\section{Hypothesis 3}

$\mathrm{H}_{0}$ : Liquidity ratio does not significantly influence non-performing loans among commercial banks in Kenya.

$\mathrm{H}_{1}$ : Liquidity ratio significantly influences non-performing loans among commercial banks in Kenya.

\section{Hypothesis 4}

$\mathrm{H}_{0}$ : Return on average assets does not significantly influence non-performing loans among commercial banks in Kenya. 
$\mathrm{H}_{1}$ : Return on average assets significantly influences non-performing loans among commercial banks in Kenya.

\subsection{Justification of the Study}

The study focused on seeking to assess the factors leading to vulnerability of NPLs amongst the CBs in Kenya banking through the assessment of bank related factors. It is worth noting that both customer related determinants, bank related factors, and macroeconomic factors such as inflation, unemployment, prices indices, bank lending rates, growth in credit and ownership, and profitability, are an integral part in determination of loan portfolio quality. Despite numerous empirical studies having assessed and addressed the core factors leading to rising NPLs cases, most of these studies have embarked on revealing the factors affecting NPLs in developed countries. Generalization of the findings from studies to banks in developing economies such as commercial banks in Kenya is difficult. Thus, applicability of the findings from the empirical studies to banks in developing economies; such as Kenyan, was difficult. The present study therefore locked the gap left by the past studies through assessment of bank related factors.

The findings from the present study would importantly seek to contribute to the understanding and analysis of factors affecting non-performing loans and to set effective and efficient credit management tools in Banks. Utilization of these findings would thus be useful to CB policy makers as they would provide insight on the ways and means of improving the loan qualities as well as reexamining their loan policy coupled with maintaining banks' asset quality effectively. This would be through the minimization of occurrence of NPLs amongst the Kenyan CBs

Evidence from Central Bank of Kenyan (2016) and empirical literature (Gathaiya, 2017; Muchoki \& Were, 2016, Genga, 2016; Musau. 2014; Muriithi, 2013; Ongore \& Kusa, 2013) have revealed that high occurrence of NPLs among commercial banks in Kenyan are a "recipe" for the financial crises in these banking institutions and the country at large. According to CBK (2016), there is increasing accumulation of NPLs among Kenyan CBs which is widely associated with common financial crises amongst these banking institutions. While Gathaiya (2017) posits that increasing accumulation of NPLs is widely associated with financial crises among Kenyan commercial banks, Genga (2016) indicates that prominent commercial banks in Kenya have actually collapsed as a results of the NPLs' accumulation. Muchoki and Were (2016) postulates that this leads to continued unhealthy operating environment within the banking sector leading challenges including financial distress. Empirical study by Musau (2014) revealed that Kenya has been experiencing banking problems since 1980s, culminating in major bank failures due to high levels of non-performing loans and Muriithi's (2013) study established that the occurrence of banking crises in Kenya has often been associated with a massive accumulation NPLs. Muriithi (2013) further revealed that NPLs are also one of the major causes of the economic stagnation in the country. Meanwhile the study by Ongore and Kusa (2013) revealed that increasing levels of NPLs are most likely capable of hindering the economic growth and impairing the economic efficiency in the country. Implementing the study findings might lead to minimization of NPLs' occurrence, which would reduce cases of financial crises amongst Kenyan CBs hence enhancing sustainability of the sector. So, this study would be beneficial to the banking sectors and more specifically, the Commercial banks. Notably, impairment of the economic efficiency and hindrance to economic growth in the country are associated with accumulation of NPLs. Thus, the country might benefit significantly from the implementation of the study findings by the CBs in that there might be reduced level of NPLs on adhering to the study findings.

The study extended the existing literature by providing fair and valid conclusions for the Kenya banking sector, thus making a beneficial asset to academician as well as scholars in the financial sector. The study further added new knowledge in the banking sector through revealing the relationship between bank specific factors and occurrences of NPLs among the CBs in Kenya. Thus, it actively contributed the body knowledge of banking industry in the financial sector.

\subsection{Delimitations}

This study faced some delimitation for instance; the study scope was limited to Kenya commercial banks and bank specific factors affecting NPLs, which was not inclusive enough to cover the entire banking industry or even the financial sector. So, it might have been difficult to generalize the study to the entire financial sector.

\section{Literature Review}

\subsection{Empirical Literature}

This section presents review of relevant empirical studies considered valuable to it as explaining effects as well on addressing the study variables and how they related to NPLs. The variables highlighted in this section are; IRS, operating efficiency, influence of liquidity ratio (LR), and effects of return on average assets (ROAA) on NPLs.

\subsubsection{Non-Performing Loans and Its Effects}

As the study conducted by Chege and Bichanga (2017) showed that ROA has significant effects on the NPLs occurrence amongst CBs in Kenya, Asfaw, Bogale and Teame's study of 2016 concludes that growth of NPL adversely impacts financial institutions' performance within the Ethiopia Central region. This was confirmed in the study by Mondal (2016), which further revealed that 
since NPL is derived from inefficiency, it critically hampers the economic growth and proficient resource allocation. The study conducted in (2016) by Chimkono, Muturi and Njeru found that the performance of banks in Malawi is affected significantly by NPL ratio while results in the study by Kristianti and Yovin (2016) show that NPL significantly influences the performance of the government banks in Indonesia as it would decrease bank's profitability. However, the study by Amoako conducted in (2015) established a negative but significant effect of NPL on the increase in bank's lending potential and a negative insignificant effect of NPL on profitability of banks. While a study by Buchory (2015) revealed a significant positive effect of NPL on performance, Duraj \& Moci's (2015) study did not find any significant effect of NPL on profitability, and the other studies such as by; Frederick (2014), Petria, Capraru \& Ihnatov (2015) as well as Ongore and Kusa (2013) established a negative significant effect of NPLs on profitability. Meanwhile as Kanu and Isu (2014) in their study found that Nigerian Gross Domestic Product (GDP) is negatively affected by increase in NPLs

\subsubsection{Bank Specific Factors and Non-Performing Loans}

Malimi conducted a study on NPLs in the Tanzanian banking sector, in the year 2017, and found that bank specific factors; capital adequacy, profitability posed insignificant influence on non-performing loans. Meanwhile, Ekanayake and Azeez (2015) conducted a study which suggests that NPLs among Sri Lankan banks are dependent on bank-specific factors. Hassana, Ilyas and Rehman's (2015) study concluded that the NPLs in Pakistan are as a result of bank-specific factors. A study conducted by Vasiliki et al. (2014) revealed that strong correlations exists between NPL and the independent variables; ROE, ROA, and capital adequacy ratio (CAR), Klein's (2013) study revealed a significant effect of bank specific factors; bank management, equity, and Loan to Total Asset Ratio (LAR) on NPLs in Central, Eastern and South- Eastern Europe (CESEE). While Messai and Jouini (2013) concluded that NPLs negative affected the bank's profitability and positively affected loan loss reserves as well as total loans advances, Warue (2013) concluded that bank specific factors significantly affected NPLs amongst CBs in Kenya.

\subsubsection{Influence of Interest Rate Spread on Non-Performing Loans}

Other studies were conducted attributing the growth of NPLs in terms of interest rate spread (IRS). For instance, a local study by Atem (2017) revealed that KCB bank's NPLs are influenced by high interest rate thereby recommending control of the interest rate. The results in the study by Ghasemi and Rostami (2016) reveal NPL was significantly correlated to IRS, such that a growth of one percent increase in NPL is associated with 0.97 per cent increase in interest rate spread. Meanwhile the paper by
Sheefeni (2016) established IRS had a positive significant effect on NPLs in Namibia. However, Mondal's (2016) study concludes that IRS has statistical negative effect on NPLs in Bangladesh. Chege's (2014) study conducted in Kenya established a negative and good linear relationship between CB's NPLs and interest rate spread.

\subsubsection{Influence of Banks Operating Efficiency on Non-Performing Loans}

The study by Kristianti and Yovin (2016) reveals a significant influence of banks operational efficiency and NPL performance amongst Indonesia government banks. Amoako conducted a study in the year (2015) which concluded that the major causes of NPLs in the bank sector are bank operating inefficiencies such as; poor loan appraisal, credit monitoring laxity, and ineffective credit management policy. The study conducted by Ekanayake and Azeez (2015) results reveal that efficiency has explanatory power over NPLs such that increased bank efficiency reduce the NPLs. The study by Hue (2015) which used ordinary least square (OLS) method for panel data indicated that bank operating efficiency factors; LAR and total assets accelerate growth of NPLs.

Sheefeni's (2015) study results reveal that the main determinants of NPLs amongst Namibia are banks operating efficiency factors; ROA, ROE, LAR where each of ROA and ROE has negative relationship with NPLs while the relationship between NPLs and LAR is positive such that when the quality assets were lowered, the NPL increased. On the other hand, the paper by Mabvure, Manuere, Edson, Clifford \& Michael (2012) revealed that NPLs in Zimbabwe are to a limited extend influenced by bank operating efficiency factors; poor bank loaning policies and inadequacy of loan monitoring and recovery as well as inadequate risk management. Swamy conducted a study in (2012) with the findings showing that a strong positive effect of LRD on NPLs level as the study by Karim while Chan and Hassan (2010) indicated that NPLs is increase by lower cost efficiency where poor bank management escalates the NPLs levels.

\subsubsection{Influence of Liquidity Ratio on Non-Performing Loans}

A global study by Islam and Nishiyama (2016) found evidence that liquidity ratio significantly explains the levels of bank NPLs. Mitku's (2014) study, which used Ordinary Least Square (OLS) technique, established a significant relationship between CB's lending and its liquidity ratio. Shingjergji's (2013) study, using OLS reveals a negative insignificant relationship between CAR and NPLs as Vatansever and Hepsen's (2013) study findings also shows a positive effect of CAR on NPL ratio. However, the study by Malimi (2017) falls short of providing significant influence of CAR on the NPLs level as the study by Gezu (2014) revealed a negative statistically significant effect of CAR on NPLs in Ethiopia 
CBs.

\subsubsection{Effects of Return on Average Assets on Non-Performing Loans}

While a regional study by Malimi (2017) shows that under regression analysis, profitability ROA does not provide significant influence on NPLs, the study by Islam and Nishiyama (2016) found evidence that bad management ROA significantly explain the levels of bank NPLs. Sheefeni (2015) study results reveal that ROA as a determinant of NPL, portraying a negative relationship between the two. As Gezu's (2014) study finding revealed a negative and a statistically significant effect of Return on Equity (ROE) on NPLs among Ethiopian CBs, the effect of ROA on NPLs in these banks was positive and statistically significant. Ahlem and Fathi's (2013) study results showed that ROA had a statistically significant negative relationship with NPLs. On contrary, Vasiliki et al. (2014) study found that ROE had positive significant effect on NPLs but that ROA had an insignificant impact on NPL ratio. Fawad and Taqadus (2013) conducted a study which established that the effect of ROA on NPL was positively statistically significant while ROE had an insignificant effect on NPLs.

\subsection{Theoretical Literature}

The study reviews various theory found useful in explaining NPLs in terms of Bank Specific factors discussed hereunder.

\subsubsection{Theory of Information Asymmetry}

The theory of asymmetric information suggests that banks and other lending institution (lenders) encounter a heavy task of distinguishing in advance those borrowers who are good from those who are bad (Auronen, 2003), which may be attributed to problems of adverse selection and moral hazards. The theory suggests that the borrower holds detailed and more information over the specific item being transacted and therefore is at an added advantage to negotiating optimal terms for the transaction as compared to the lender (Bester, 1994). Accordingly, the party not adequately informed about the specific items of the transaction is at the mercy of the more informed party (Auronen, 2003). Considering that the banks, who are the lenders, may know less about the specific item being transacted, they should therefore seek to possess superior ability for overcoming the information asymmetry problems and have the ability to reduce the NPLs. Thus, based on asymmetric information, CBs should importantly gather appropriate and adequate information necessary to ascertain the factors that actively propagate proliferation of NPLs. This would put the CBs in a position to mitigate proliferation of NPLs since acquisition of the appropriate information enhances the lender to distinguish between the right decision and the wrong decision (Auronen, 2003). So as to avoid making the wrong decision concerning minimization of the level of NPLs, the Kenyan CBs should establish the bank specific factors influencing NPLs in the sector. Based on these suggestions by the theory, the present study then was motivated to analyze the bank related factors that influence the proliferation of NPLs among CBs in Kenya based on the Theory of Information Asymmetry.

\subsubsection{Loan Pricing Theory}

According to the suggestions by the loan pricing theory, banks are not expected to occasionally set their interest rates decision concerning the transaction, which means that they don't try to earn maximum interest income when lending (Mudzingwa, 2013). So, when the banks interest rates are to be very high, the banks may face adverse selection problems since only high-risk borrowers are the ones who would willing seek for loans pegged on high rates. However, when such borrowers receiving the anticipated loans, they are most likely to develop moral hazards in their behaviour, leading them into investing in highly risky projects which have greater potential of recouping the higher interest rate payments (Chodechai, 2004).

The loan pricing theory is very useful for it regards interest rate spread as a factor affecting NPL among the Kenyan CBs. The theory suggests that the banks should devise mechanisms for recognizing and realizing the potential risk the borrower bears and in event they seek to charge a lower interest rate in their effort to reduce the interest burden on its loans. One way of reducing the interest burden is through interest rate spread (IRS). This is made possible by individual CBs having the liberty to set their distinctive interest rate spread (Sheefeni, 2016).

\subsubsection{The Economic Theory}

The correlation between the four variables; interest rate spread, banks operating efficiency, liquidity ratio, return on average assets and Non-Performing loans is broadly in line with economic theory (Klein, 2013).

\section{Research Methodology}

\subsection{Research Design}

Research design, being the map developed to guide the research, is; part of planning stage and a master plan blueprint for guiding the ways data was; collected, measured and analysed. It specifies the most suitable methods and procedures for collecting study data as well as the appropriate data analysis methods, detailing all the tasks concerned with working out the condition of conducting a research. Research design addresses the questions; why the study being is conducted, what the study was all about, when the study was carried out, where 
the study was conducted. what kind of data was required, where required data was available, what technique was used for collecting data, what method of data collection was adopted, what method of sampling was used, and what was the format of reporting the data (Gupta \& Rangi, 2014). The study used descriptive research design to describe the bank specific factors affecting the NPLs.

\subsection{Target Population}

Lavrakas (2008) postulates that the study target population comprises of all elements (subjects) or units possessing similar characteristics and for which the research findings would be generalize. It is from the target population that the sample provide the data is drawn from. The target population was the 43 current commercial banks licensed under the Kenyan Banking Act operating during the period under review from 2012 to 2016.

\subsection{Sampling Procedures and Techniques}

Kothari (2012) indicates that the parameters of the entire study population are determined by the technique used for sampling to select the most suitable sample. Since the study population was small, easily accessible and manageable the study used census, a non-probability method where the entire target population participated in the study as respondents. Mugenda and Mugenda (2008) suggest that when the target population does not exceed 100 subjects, then study should consider using census for sampling. Thus, the sample population was 43 respondents, who comprised the 43 licensed CB operating in Kenya.

\subsection{Data Collection Instruments and Procedures}

Due to the nature of financial studies, the study used secondary data sources, which was sourced from statistical records maintained by the various institutions such as CBK the regulatory body supervising the banking industry in Kenya. This data was collected using a researcher designed data collection sheet (institutional tool). Data of interest included; total deposits, average interest charges on loans, average interest paid on deposits, operating expenses, operating income, CBs' asset, funding ratio (mainly short term), net income before taxes and average total assets (opening assets balance, closing assets balance). The rationale behind the choice of secondary data is guided by the study using financial variables which mainly rely on historical data held in secondary data.

Data collection encompassed; collecting secondary data where it gathers, assembles and accumulates the appropriate information (treated as data) from the respective sources. The present study used secondary data gathered from various institutions. This data included published financial statements of CBs operating in Kenya and banking supervision reports held by CBK, as well as Kenya National Bureau of Statistics (KNBS), covering the period from the year 2012 to 2016. This study employed time series approach because it gives more informative and reliable data. The time series covered a period of 5 years from 2012 to 2016.

\subsection{Data Analysis Techniques and Procedure}

When the study had successfully gathered, assembled and accumulated the entire set of the desired data, it manually checked for errors of omission and commissions. Any data not found comprehensive or irrelevant was discarded as the rest was analysed. The analysis was done using quantitative data analysis, which is the most convenient way of produce the most useful descriptive statistics. The study used quantitative data analysis to produce descriptive statistics which summarized information (results) including; frequencies, means, percentage, modes and standard deviation. The descriptive statistics, which were the properties and patterns of the study variables. The operationalization of the study variables.

Table 1. Operationalisation of study Variables

\begin{tabular}{|c|c|c|c|c|c|}
\hline Variables & Type & Notation & Description & Scale & Method \\
\hline \multirow{2}{*}{$\begin{array}{l}\text { Non-Performing } \\
\text { Loan(NPL) }\end{array}$} & \multirow{2}{*}{$\begin{array}{c}\text { Dependent } \\
\text { Variable (DV) }\end{array}$} & \multirow{2}{*}{ NPL/TL } & \multirow{2}{*}{$\begin{array}{c}\text { (Non-performing loans / total } \\
\text { loans) } \%\end{array}$} & Ratio & Descriptive \\
\hline & & & & & Regression \\
\hline \multirow{2}{*}{$\begin{array}{l}\text { Interest Rate } \\
\text { Spread (IRS) }\end{array}$} & \multirow{2}{*}{$\begin{array}{l}\text { Independent } \\
\text { Variable (IV) }\end{array}$} & & \multirow{2}{*}{$\begin{array}{c}\text { Average Interest charges on } \\
\text { Loans - Average interest paid } \\
\text { on deposits \% }\end{array}$} & Ratio & Descriptive \\
\hline & & & & & Regression \\
\hline \multirow{2}{*}{$\begin{array}{l}\text { Bank Operational } \\
\text { efficiency (BOE) }\end{array}$} & \multirow{2}{*}{ IV } & \multirow{2}{*}{ LTD } & \multirow{2}{*}{ Loans divided by Deposits\% } & Ratio & Descriptive \\
\hline & & & & & Regression \\
\hline \multirow[b]{2}{*}{$\begin{array}{l}\text { Liquidity ratio } \\
\text { (LR) }\end{array}$} & \multirow[b]{2}{*}{ IV } & \multirow[b]{2}{*}{ (LA/ (TD\& STF) } & \multirow{2}{*}{$\begin{array}{l}\text { Liquid asset to total deposits } \\
\text { and short term funding ratio } \\
\text { (\%) express the liquidity } \\
\text { position of a bank }\end{array}$} & Ratio & Descriptive \\
\hline & & & & & Regression \\
\hline \multirow{2}{*}{$\begin{array}{c}\text { Return On } \\
\text { Average Asset } \\
\text { (ROA) } \\
\end{array}$} & \multirow[b]{2}{*}{ IV } & \multirow[b]{2}{*}{ NI/ATA } & \multirow{2}{*}{$\begin{array}{l}\text { Net income before taxes } \\
\text { divided by average total } \\
\text { assets } \%\end{array}$} & Ratio & Descriptive \\
\hline & & & & & Regression \\
\hline
\end{tabular}


The study attempted to establish evidence of relationship that existed between bank specific factors and NPLs among CBs operating in Kenya using inferential statistics; correlation and regression analysis, at 5\% level of significance. The study then sought to predict a study model, where the significance of the fitness of the model was established using Analysis of Variance (ANOVA) at 5\% (probability value, $\mathrm{p}$-value $\leq 0.05$ ) level of significance. The study first carried out a correlation analysis using Pearsons Product Moment at 5\% level of significance to establish whether each of; interest rate spread, banks operating efficiency, liquidity ratio and return on average assets had relationship with NPLs among CBs in Kenya. The study further carried out multiple regression to establish the nature of relationship as well as whether the IVs; interest rate spread, banks operating efficiency, liquidity ratio and return on average assets are predictors of the DV; NPLs among Kenyan CBs and therefore provide for development of a study model. This regression model was;

$$
Y=\beta_{0}+\beta 1 X_{1}+\beta 2 X_{2}+\beta 3 X_{3}+\beta 4 X_{4}+\varepsilon
$$

Where:

$\mathrm{Y}=$ NPLs of bank

$\beta o$ is the constant term (intercept),

$\beta 1 \ldots \beta 4$ are the coefficients of the IVs of the study: $X_{1}, X_{2}$, $\mathrm{X}_{3}$, and $\mathrm{X}_{4}$ respectively (that IRS, banks operating efficiency, LR and ROA respectively)

$$
\varepsilon=\text { error term. }
$$

\section{Research Findings, Analysis and Presentation}

\subsection{Descriptive Statistics}

The study first produced descriptive statistics which summarized the results of analysis, including; frequencies, means, standard deviation and other properties. Table 2 captures the; number of observations $(\mathrm{N})$, mean, standard deviation, maximum, and minimum, for each study variables.

According to table 2 there were 215 observations of the Kenyan CBs from the year 2012 to 2016 on NPLs and bank specific factors; IRS, OE, LR and ROA. These results show that NPLs ratio (measured as percentage of
Non-performing loans divided by gross loan has a minimum value of $0.00 \%$ and maximum of $54.99 \%$. ranging from $0.00-54.99 \%$ percent. It has a mean of $8.18 \%$ and standard deviation of 8.35 , implying the lowest deviation was $(-0.17 \%)$ from the mean value of NPL ratio. Based on these results, the Kenyan Commercial banks incurred an average $8.18 \%$ NPLs from its gross loan. The prudential guidelines of the CBK require the Kenyan banking sector to be maintaining NPLs ratio not exceeding $5 \%$ (CBK, 2016b). The mean NPLs ratio of $8.18 \%$ indicated that the NPLs of Kenyan CBs are more than the required threshold of $5 \%$. This portrays a serious NPLs problem amongst the Kenyan CBs. These findings are a confirmation by CBK (2016) that there is increasing accumulation of NPLs among Kenyan CBs, which is widely associated with bank failures and common financial crises amongst Kenya CBs.

Results on IRS indicate that Kenyan CBs earn an average of $6.75 \%$ spread on their earning assets, where the minimum IRS is $0.00 \%$ and the maximum IRS value was $19.06 \%$. These results are an indication that most efficient banks earn $0.00 \%$ IRS and the most inefficient banks earn $6.75 \%$ spread. The Standard deviation was 3.35\% for IRS, with the highest deviation from the mean value being $3.40 \%$. This indicates that the spread variation from its mean was low spread from the mean.

Regarding banks operating efficiency (OE), the results show that the minimum value was $0.00 \%$ while the maximum of OE was $250.04 \%$. The mean (M) value of OE was shown to be $72.18 \%$ while its standard deviation was $34.67 \%$. This implies that the highest deviation from the mean $(\mathrm{M})$ was therefore $27.51 \%$. Based on these results, OE had a high deviation of $27.51 \%$ whereas NPLs had a low deviation of $-0.17 \%$ from its $\mathrm{M}$.

The results on liquidity risk (LR) indicated the $M$ was $38.87 \%$ which implies that there was availability of cash. This was because the cash equivalent assets were shown to be on average at $38.87 \%$ per year. Thus the CB was able to repay short term liabilities, where they had about Ksh 3 and eighty cents liquid asset to repay Ksh.1 short term liabilities. The maximum and minimum values of liquidity risk are $141.80 \%$ and $0.00 \%$ respectively and also the standard deviation was $21.44 \%$, the highest deviation from the mean (M) was $17.43 \%$, which indicates that there were high variations from the mean.

Table 2. Descriptive Statistics of independent and dependent variables

\begin{tabular}{|c|c|c|c|c|c|}
\hline & Non-Performing Loans & Interest Rate Spread & $\begin{array}{c}\text { Operating } \\
\text { Efficiency }\end{array}$ & $\begin{array}{c}\text { Liquidity } \\
\text { Ratio }\end{array}$ & $\begin{array}{c}\text { Return on average } \\
\text { assets }\end{array}$ \\
\hline $\mathrm{N}$ & 215 & 215 & 215 & 215 & 215 \\
\hline Mean & 8.18 & 6.75 & 72.18 & 38.87 & 2.34 \\
\hline Std. Deviation & 8.35 & 4.21 & 34.67 & 21.44 & 2.99 \\
\hline Minimum & 0.00 & 0.00 & 0.00 & 0.00 & -13.58 \\
\hline Maximum & 54.99 & 19.06 & 250.04 & 141.80 & 10.39 \\
\hline
\end{tabular}

Source: Research data (2018) 
The results on ROA shows that average profitability was $2.34 \%$. This means, on the average, from each Ksh 1. Investment in the asset there was 2.34 cent return. The maximum value of return on asset for the year was 10.39 whereas the minimum value was $-13.58 \%$. Also the standard deviation was $2.99 \%$ which indicates there was very low variation from the mean. The lowest standard deviation was -0.65 . Despite the high ROA reporting better performance in the management of available assets, there was low performance amongst Kenya CBs shows as relates to their ROA. In fact, the Kenyan CBs earned high return from their own assets.

\subsection{Inferential Analysis}

The study then proceeds to establish whether the IVs; IRS, OE, LR, and ROA would be predictors of DV, NPLs among Kenyan CBs. The study first carried out correlation analysis, using Pearson's correlation to establish whether there was any relationship between the IVs and the DV. Thereafter regression analysis was carried out to establish a study model.

\subsubsection{Classical Linear Regression Model (CLRM) Assumptions Tests}

In maintaining the validity and robustness of the regression model, the study tested the data to satisfy basic assumption CLRM (Brooks, 2008). On satisfying assumptions, then all available information is considered as used in the model. However, violation of these assumptions implies that some data is left out of the model. In this section, the study tested for; multicollinearity, heteroscedasticity and autocorrelation to ensure quality of the research.

\subsubsection{Multicollinearity Tests}

Table 3. Test for Multicollinearity on Independent variables

\begin{tabular}{|c|c|c|}
\hline \multirow{2}{*}{ Variable } & \multicolumn{2}{|c|}{ Collinearity Statistics } \\
\cline { 2 - 3 } & Tolerance & $\begin{array}{c}\text { Variance Inflation Factor } \\
\text { (VIF) }\end{array}$ \\
\hline Interest Rate Spread & 0.684 & 1.463 \\
\hline Operating Efficiency & 0.746 & 1.341 \\
\hline Liquidity Ratio & 0.909 & 1.101 \\
\hline $\begin{array}{c}\text { Return on average } \\
\text { assets }\end{array}$ & 0.966 & 1.035 \\
\hline
\end{tabular}

Source: Research data (2018)

Multicollinearity occurs when IVs are highly correlated with one another that they share the same information. Thus, the multicollinearity problem reduces the individual IVs' predictive power. In this case none of the predictor variables may contribute uniquely and significantly to the prediction model after the other independent variables is included. Multicollinearity. Multicollinearity exists when variance inflation factor (VIF) is more than 10 and tolerance is less than 0.1 or $10 \%$ (Fawad \& Taqadus, 2013). The results obtained through tests for multicollinearity are shown in Table 3.

The results in show that the tolerance for; interest rate spread was 0.684 , operating efficiency was 0.746 , liquidity ratio was 0.909 , and return on average assets was 0.966 . The tolerance for each IV (predictor variable) was greater than 0.1 , which implies that there were no multicollinearity problems among the IVs. So, the estimators computed were considered reliable for estimating the study model.

\subsubsection{Heteroscedasticity Test}

Heteroscedasticity occurs when the variance of each error term is different (Babulo \& Hassen, 2005). The study tested for heteroscedasticity at $5 \%$ level of significance and there would have been heteroscedasticity when p-value $\geq$ 0.05 . This test states that if the P-value is significant at $95 \%$ confidence interval, the data has heteroscedasticity problem, whereas if the p-value is insignificant (greater than 0.05 ), the data has no heteroscedasticity problem. The results on heteroscedasticity tests were captured in Table 4.

Table 4. Results on Heteroscedasticity test

\begin{tabular}{|c|c|c|}
\hline Variable & T-statistics (t) & Probability value (Sig.) \\
\hline Interest Rate Spread & -1.322 & 0.188 \\
\hline Operating Efficiency & .832 & 0.407 \\
\hline Liquidity Ratio & -.174 & 0.862 \\
\hline $\begin{array}{c}\text { Return on average } \\
\text { assets }\end{array}$ & -.295 & 0.768 \\
\hline
\end{tabular}

Source: Research data (2018)

The results in table 4 show that the p-value for each IV was greater than 0.05 ; interest rate spread (p-value $=0.188$ ), operating efficiency ( $\mathrm{p}$-value $=0.407$ ), liquidity ratio (p-value $=0.862)$, and return on average assets $(\mathrm{p}$-value $=$ 0.768). This implies than there was no presence of heteroscedasticity problems in the study data.

\subsubsection{Autocorrelation Tests}

The study tested the auto-correlation assumptions that imply zero covariance of error terms over time. That means errors linked to an observation are not correlated with the errors of another specific observation. The study used the best renowned test for detecting serial correlation, Durbin Watson test. The results show that the Durbin-Watson was 1.9658 which was between the 1.5 and 2.5. So, there was no auto-correlation between the data items.

\subsubsection{Correlation Analysis}

The study first tested for existence of statistically significant relationship between the IVs and the DV by carrying out correlation analysis to obtain results captured in table 5 below. 
Table 5. Results on Correlation analysis of Study variables

\begin{tabular}{|c|c|c|c|c|c|c|}
\hline \multicolumn{7}{|c|}{ Correlations } \\
\hline & & $\begin{array}{l}\text { Non- Performing } \\
\text { Loans }\end{array}$ & $\begin{array}{l}\text { Interest Rate } \\
\text { Spread }\end{array}$ & $\begin{array}{l}\text { Operating } \\
\text { Efficiency }\end{array}$ & $\begin{array}{l}\text { Liquidity } \\
\text { Ratio }\end{array}$ & $\begin{array}{c}\text { Return on } \\
\text { average } \\
\text { assets }\end{array}$ \\
\hline \multirow{3}{*}{$\begin{array}{l}\text { Non- Performing } \\
\text { Loans }\end{array}$} & $\begin{array}{c}\text { Pearson } \\
\text { Correlation }\end{array}$ & 1 & $.163^{*}$ & $.308^{* *}$ & -.118 & $-.398^{* * *}$ \\
\hline & Sig. (2-tailed) & & .017 & .000 & .084 & .000 \\
\hline & $\mathrm{N}$ & 215 & 215 & 215 & 215 & 215 \\
\hline \multirow{3}{*}{ Interest Rate Spread } & $\begin{array}{c}\text { Pearson } \\
\text { Correlation }\end{array}$ & $.163^{*}$ & 1 & $.495^{* *}$ & $.255^{* *}$ & $.136^{*}$ \\
\hline & Sig. (2-tailed) & .017 & & .000 & .000 & .047 \\
\hline & $\mathrm{N}$ & 215 & 215 & 215 & 215 & 215 \\
\hline \multirow{3}{*}{$\begin{array}{l}\text { Operating } \\
\text { Efficiency }\end{array}$} & $\begin{array}{c}\text { Pearson } \\
\text { Correlation }\end{array}$ & $.308^{* *}$ & $.495^{* *}$ & 1 & .032 & .076 \\
\hline & Sig. (2-tailed) & .000 & .000 & & .640 & .268 \\
\hline & $\mathrm{N}$ & 215 & 215 & 215 & 215 & 215 \\
\hline \multirow{3}{*}{ Liquidity Ratio } & $\begin{array}{c}\text { Pearson } \\
\text { Correlation }\end{array}$ & -.118 & $.255^{* *}$ & .032 & 1 & -.086 \\
\hline & Sig. (2-tailed) & .084 & .000 & .640 & & .210 \\
\hline & $\mathrm{N}$ & 215 & 215 & 215 & 215 & 215 \\
\hline \multirow{3}{*}{$\begin{array}{l}\text { Return on average } \\
\text { assets }\end{array}$} & $\begin{array}{c}\text { Pearson } \\
\text { Correlation }\end{array}$ & $-.398^{* *}$ & $.136^{*}$ & .076 & -.086 & 1 \\
\hline & Sig. (2-tailed) & .000 & .047 & .268 & .210 & \\
\hline & $\mathrm{N}$ & 215 & 215 & 215 & 215 & 215 \\
\hline
\end{tabular}

*. Correlation is significant at the 0.05 level (2-tailed).

**. Correlation is significant at the 0.01 level (2-tailed).

Source: Research Data (2018)

Based on these results, there exists a significant relationship between each IV and DV and this was high because the correlation coefficient (r) for each comparison between an IV and DV was less than 0.5. The result show that had Return on average assets had the highest relationship ( $r=-0.398)$, followed by operating efficiency $(r=0.308)$, then Interest rate spread $(r=0.163)$ and lastly Liquidity ratio $(r=-0.118)$. From the results; Interest rate spread $(r=0.163$; $p$-value $=0.017)$, operating efficiency $(r$ $=0.308 ; \mathrm{p}$-value $=0.000)$, then and lastly Liquidity ratio $(\mathrm{r}$ $=-0.118$; $\mathrm{p}$-value $=0.084$ ), and Return on average assets the highest relationship $(r=-0.398$; $p$-value $=0.047)$ were each significantly related to NPLs among Kenya CBs. The result show that each of; return on average assets $(r=$ $0.398)$, and operating efficiency $(r=0.308)$ had moderate relationship since correlation coefficient $(r)$ was between 0.3 and 0.6 while interest rate spread $(r=0.163)$ and lastly liquidity ratio $(r=-0.118)$ had a low correlation coefficient (r) was less than 0.3. From these results, both interest rate spread $(r=0.163)$ and operating efficiency $(r=0.308)$ had significant positive relationship while each of liquidity ratio $(r=-0.118)$ and return on average assets $(r=-0.398)$ had a negative relationship with NPLs among Kenya CBs.

\subsubsection{Regression Analysis}

Multiple regression was then carried out on the IV (IRS, OE, LR, and ROA) against the dependent variable (NPLs among Kenya CBs) to estimate the model, since they were found to have a significant relationship. The IVs and DV were therefore regressed to estimate the study model in equation (i).

The study carried out an Analysis of Variance (ANOVA) to estimate the model fitness, and these results are captured in Table 6 below;

The study tested the fitness of the model guided by the hypothesis that;

$\mathrm{H}_{0}: \beta_{1}=\beta_{2}=\beta_{3}=\beta_{4}=0$ (that is the beta values coefficient of $\mathrm{X}_{1}, \mathrm{X}_{2}, \mathrm{X}_{3}$ and $\mathrm{X}_{4}$, are all zero) and the proposed alternate hypothesis was therefore that; 
Table 6. ANOVA for non-performing loans among commercial banks in Kenya

\begin{tabular}{|c|c|c|c|c|c|}
\hline \multicolumn{7}{|c|}{ ANOVA } \\
\hline & Sum of Squares & df & Mean Square & F & Sig. \\
\hline Regression & 4681.872 & 4 & 1170.468 & & \\
\hline Residual & 10236.614 & 210 & 48.746 & & \\
\hline Total & 14918.485 & 214 & & & \\
\hline a. Dependent Variable: Non Performing Loans \\
\hline
\end{tabular}

Source: Research Data (2018)

$\mathrm{H}_{\alpha}$ : At least one the beta value: $\beta_{\mathrm{i}} \neq 0$

The testing was at $5 \%$ level of significance, where $\mathrm{H}_{0}$ was to be accepted if probability value (p-value) was greater than 0.05 that is p-value $>.05$. In this case, $\mathrm{H}_{\alpha}$ was to be rejected. Where $\mathrm{H}_{0}$ was less than or equal to 0.05 (p-value $<=0.05$ ) then $\mathrm{H}_{\alpha}$ was accepted and $\mathrm{H}_{0}$ was rejected.

The results ( $\mathrm{p}$-value $=0.000, \mathrm{~F}=25.439$ ), show that the $\mathrm{p}$-value $<0.05$. Based on these results, then $\mathrm{H}_{0}$ was rejected and $\mathrm{H}_{\alpha}$ was accepted because p-value $<0.05$. then study can conclude that at $\alpha=0.05$, there exists enough evidence to conclude that at least one of the IVs; interest rate spread, operating efficiency, liquidity ratio, and return on average assets are useful in estimating the non-performing loans among commercial banks in Kenya and hence the study can estimate a model explaining non-performing loans among commercial banks in Kenya in terms of; interest rate spread, operating efficiency, liquidity ratio, and return on average assets. The result in Table 6 shows that the regression model is significant with $F$ statistic of 24.012 and $\mathrm{P}<0.000$ which indicates that the points lie moderately close to the line of best fit in the scatter diagram. This indicates that the model is relatively suitable in explaining the variance of levels of NPLs as explained by the variance in the bank specific factors.

The IVs and DV were then regressed to estimate the study model. The study obtained result shown in Table 7.

The study used the following hypotheses to test for effects of interest rate spread;

$\mathrm{H}_{0}$ : Interest rate spread has no significant influence on non-performing loans among commercial banks in Kenya.

$\mathrm{H}_{1}$ : Interest rate spread has significant influence on non-performing loans among commercial banks in Kenya.

The results in Table 7 show that at 0.05 significance level, $\mathrm{p}$-value $=0.050$ and $\mathrm{T}=1.970$. Then the $\mathrm{H}_{0}$ is rejected and $H_{1}$ Since the p-value does not exceed 0.05 . Accordingly, the study concludes that at $\alpha=0.05$ significant levels, there is enough proof to suggest that the interest rate spread is not zero and therefore interest rate spread is useful as an estimator of non-performing loans among commercial banks in Kenya.

The study used the following hypotheses to test for influence of operating efficiency;
$\mathrm{H}_{0}$ : Banks operating efficiency does not significantly influence the non-performing loans among commercial banks in Kenya.

$\mathrm{H}_{1}$ : Banks operating efficiency significantly influences the non-performing loans among commercial banks in Kenya.

The results in Table 7 show that at 0.05 significance level, p-value $=0.000$ and $\mathrm{T}=4.257$. Then the $\mathrm{H}_{0}$ is rejected and $H_{1}$ Since $\mathrm{p}<0.05$. Accordingly, the study concludes that at $\alpha=0.05$ significant levels, there is enough information to proof that the operating efficiency is not zero and therefore operating efficiency is useful as an estimator non-performing loans among commercial banks in Kenya.

The influence of liquidity ratio was tested using the hypotheses;

$\mathrm{H}_{0}$ : Liquidity ratio does not significantly influence non-performing loans among commercial banks in Kenya.

$\mathrm{H}_{1}$ : Liquidity ratio significantly influences non-performing loans among commercial banks in Kenya.

The results in Table 7 show that at 0.05 significance level, $\mathrm{p}$-value $=9.001$ and $\mathrm{T}=-3.354$. Then the $\mathrm{H}_{0}$ is rejected and $H_{1}$ Since $\mathrm{p}<0.05$. Accordingly, the study concludes that at $\alpha=0.05$ level of significance, there is enough information to proof that the liquidity ratio is not zero and therefore liquidity ratio is useful as an estimator of non-performing loans among commercial banks in Kenya

Lastly, influences of return on average assets were tested using the hypotheses;

$\mathrm{H}_{0}$ : Return on average assets does not significantly influence non-performing loans among commercial banks in Kenya.

$\mathrm{H}_{1}$ : Return on average assets significantly influences non-performing loans among commercial banks in Kenya.

The results in Table 7 show that at 0.05 significance level, p-value $=0.000$ and $\mathrm{T}=-7.824$. Then the $\mathrm{H}_{0}$ is rejected and $H_{1}$ Since $\mathrm{p}<0.05$. Accordingly, the study concludes that at $\alpha=0.05$ level of significance, there is enough evidence that the return on average assets is not zero and therefore return on average assets is useful as an estimator of non-performing loans among commercial banks in Kenya. 
Table 7. Regression Results of Dependent Variable against Predictor Variables

\begin{tabular}{|c|c|c|c|c|c|}
\hline \multicolumn{6}{|c|}{ Coefficients' } \\
\hline & \multicolumn{2}{|c|}{ Unstandardized Coefficients } & $\begin{array}{c}\text { Standardized } \\
\text { Coefficients }\end{array}$ & \multirow{2}{*}{$\mathrm{t}$} & \multirow{2}{*}{ Sig. } \\
\hline & B & Std. Error & Beta & & \\
\hline (Constant) & 7.474 & 1.432 & & 5.219 & 0.000 \\
\hline Interest Rate Spread & 0.270 & 0.137 & 0.136 & 1.97 & 0.050 \\
\hline Operating Efficiency & 0.068 & 0.016 & 0.282 & 4.257 & 0.000 \\
\hline Liquidity Ratio & -0.078 & 0.023 & -0.201 & -3.354 & 0.001 \\
\hline Return on average assets & -1.27 & 0.162 & -0.455 & -7.824 & 0.000 \\
\hline
\end{tabular}

Source: Research Data (2018)

From the results in Table 7 , interest rate spread, operating efficiency, liquidity ratio, and return on average assets were significant estimators of non-performing loans among commercial banks in Kenya since the p-value for each predictor variable was less than 0.05 . This was an indication that there was a significant relationship between each IV; interest rate spread, operating efficiency, liquidity ratio, and return on average assets and the DV; non-performing loans among commercial banks in Kenya. This is to say that all the predictor variables i.e. interest rate spread, operating efficiency, liquidity ratio, and return on average assets can estimate the response, non-performing loans among commercial banks in Kenya. In terms of significance level (corresponding p-value), all explanatory variables had $\mathrm{p}$-values of less than the $5 \%$ significance levels. Interest rate spread ( $\mathrm{p}$-value $=0.050$ ), operating efficiency $(\mathrm{p}$-value $=0.000)$, liquidity ratio ( $\mathrm{p}$-value $=$ $0.001)$, and return on average assets ( $\mathrm{p}$-value $=0.000)$. This indicates that operating efficiency ( $\mathrm{p}$-value $=0.000)$, and return on average assets ( $\mathrm{p}$-value $=0.000)$ had strong and statistically significant $(\mathrm{p}$-value $=0.000)$ impact on the level of NPLs even at $1 \%$. Meanwhile interest rate spread $(\mathrm{p}$-value $=0.050)$ and liquidity ratio $(\mathrm{p}$-value $=0.001)$ had a statistically significant impact on the level of NPLs at $5 \%$.

The coefficient for interest rate spread $\left(\beta_{1}=.270\right)$, operating efficiency $\left(\beta_{2}=.068\right)$, liquidity ratio $\left(\beta_{3}=-.078\right)$, and return on average assets $\left(\beta_{4}=-1.270\right)$ were used to estimated model fitted as;

$$
\mathrm{Y}=7.474+0.270 \mathrm{X}_{1}+0.068 \mathrm{X}_{2}-0.078 \mathrm{X}_{3}-1.270 \mathrm{X}_{4}
$$

The fitted regression equation is in the form of: NPLs $=$ $7.474+0.270$ (interest rate spread) +0.0671 (operating efficiency) -0.078 (liquidity ratio) -1.270 (return on average assets). This inferred that the constant levels of non-performing loans before incorporating the bank specific factors is 7.474. Through the examination of coefficients for bank specific factors, liquidity ratio and return on average assets had negative impact on NPLs having a coefficient of -0.0 .78 and -1.270 respectively. This indicates that one unit change in liquidity ratio and return on average assets can result a change on NPLs rate of -0.078 and -1.270 units in opposite direction respectively. However, interest rate spread had positive impact on NPLs having a coefficient of 0.270 which implies one unit change in interest rate spread can result a change on NPLs rate by 0.270 units in the same direction. Operating efficiency also had positive impact on NPLs having a coefficient of 0.068 which indicates one unit change in operating efficiency can result a change on NPLs by 0.068 units.

The coefficients of; interest rate spread and operating efficiency are positive, indicating that they are directly proportional to the non-performing loans among commercial banks in Kenya. Therefore, an increase in any of these variables; interest rate spread and operating efficiency leads to an increase in non-performing loans among commercial banks in Kenya and vice versa. The results show that liquidity ratio and return on average assets have negative coefficients, therefore, they are indirectly proportional to the non-performing loans among commercial banks in Kenya. Hence increase in any of liquidity ratio, and return on average assets leads to and decrease in non-performing loans among commercial banks in Kenya and a decrease in liquidity ratio, and return on average assets leads to an increase in non-performing loans within commercial banks in Kenya.

Lastly,the study model was obtained as shown in table 8. 
Table 8. Model Summary for non-performing loans among commercial banks in Kenya

\begin{tabular}{|c|c|c|c|}
\hline \multicolumn{3}{|c|}{ Model Summary } \\
\hline $\mathrm{R}$ & $\mathrm{R}$ Square & Adjusted R Square & Std. Error of the Estimate \\
\hline $.560 \mathrm{a}$ & 0.3138 & 0.3008 & 6.98182 \\
\hline \multicolumn{2}{|c|}{ a. Predictors: (Constant), Return on average assets, Operating Efficiency, Liquidity Ratio, Interest Rate Spread } \\
\hline
\end{tabular}

Source: Research Data (2018)

The coefficient of determination was .3138, an indication that $31.38 \%$ of variation in non-performing loans among commercial banks in Kenya is explained by change in; interest rate spread, operating efficiency, liquidity ratio, and return on average assets. Therefore, all the variable; interest rate spread, operating efficiency, liquidity ratio, and return on average assets are strong determinants of non-performing loans among commercial banks in Kenya.

The conclusions based on the study objectives are;

1. Interest rate spread has positive significant influence on non-performing loans among commercial banks in Kenya.

2. Banks operating efficiency has positive significant influence on the non-performing loans among commercial banks in Kenya.

3. Liquidity ratio has a negative significant influence non-performing loans among commercial banks in Kenya.

4. Return on average assets has a negative significant influence non-performing loans among commercial banks in Kenya.

\section{Conclusions and Recommendations}

\subsection{Conclusions}

The study revealed that the average NPLs among Kenyan CBs is higher than the threshold of $5 \%$ as prescribed in the prudential guidelines of the CBK, signaling a serious NPLs problem amongst the Kenyan CBs manifesting itself in form of tremendous growth in accumulation of NPLs. The increasing accumulation of NPLs among Kenyan CBs is widely associated with bank failure and financial crises of commercial banks in Kenya. The tremendous growth of NPLs might adversely affect the commercial banking sector of the banking industry in Kenya and may results into financial crises in the banking sectors through undermining the net income and endangering sustainability as well as impairing Kenya's economic efficiency. Growth of accumulation of as NPLs reduces operating profit, funds available for loans, and liquidity.

The study concludes that interest rate spread has positive significant influence on NPLs, where an increase in IRS results into an increase in NPLs and vice versa. An increase of one unit in interest rate spread results in a growth rate of
0.270 on NPLs and a drop of one unit in interest rate spread results in a reduction rate of 0.270 on NPLs. So, IRS influences the occurrences of NPLs among the Kenya CBs. IRS is also a premium for the risk that the banks undertake and it compensates for loan defaults and for risk related to cost of funding, acting as a measure of bank efficiency as well as a CBs determinant of intermediation cost and profitability. IRS is significantly correlated to NPLs. However, there is widening of the gap of the IRS, which is an indication of lack of proper assessment of the market to establish the market demands. High IRS indicates that there is uncertainty in market and therefore the banks are not certain of what to give to the market. This is uncertainty is attributable to the failure by the banks to explore the market requirements and demands extensively and lack of adequately assessing the marketing expectations.

The study concludes that operating efficiency is directly proportional to NPLs and it has a positive significant influence on the non-performing loans among commercial banks in Kenya. An increase in operating efficiency leads to an increase in non-performing loans among commercial banks in Kenya and vice versa. The operating efficiency has a positive coefficient of 0.068 which indicates that an increase of one unit in operating efficiency results on rate of increase of 0.068 units on NPLs and vice versa. There is a steady increase in operating efficiency amongst Kenyan CBs is leading to high operating efficiency, which is an indication that the banks are lending almost everything at their disposal. Lending everything is very risky for commercial banks and the entire banking industry in the country since it means that the banks are lending to too many borrowers some of whom may not have the capacity to honor their promise of repay the loans resulting in uncontrollable occurrences of NPLs. Such occurrences are indications of poor credit assessment, the major bank specific factors contributing to growth of NPLs. The occurrences of NPLs are accelerated by inability of the banks to effectively manage their credit risk and lack of credit monitoring. This is attributed to by the banks' high indiscriminately risky lending, which results into the banks being at high risk of not effectively recovering the entire loan adequately. This is an unhealthy practice because they are unable to recover the outstanding loans hence growing NPLs occurrence. The indiscriminate risky lending is simply diversion of funds for unnecessary expansion of business and speculations leading to investing in high risk assets to earn high returns. Such behavior highly attracts growth of NPLs occurrence. The Kenyan commercial 
banks are suffering from operating inefficiencies which accelerate growth of NPLs.

The study concludes that liquidity ratio is negatively correlated to NPLs and has significant negative relationship with NPLs. Thus, liquidity ratio is indirectly proportional to NPLs, where liquidity ratio has a negative significant influence non-performing loans among commercial banks in Kenya. Thus, an increase in liquidity ratio leads to decreases in non-performing loans among commercial banks in Kenya and a decrease in liquidity ratio leads to an increase in non-performing loans among commercial banks within Kenya.

The study infers that return on assets is significantly correlated to NPLs and has a negative significant influence on NPLs among commercial banks in Kenya. ROA has a negative impact of 1.270 (coefficient of -1.270) on NPLs, implying that when ROA increase by 1 unit, NPLs reduce by a rate of 1.270 levels and when ROA decreases by 1 unit, the NPLs increases by a rate of 1.270 units. ROA is indirectly proportional to the NPLs among commercial banks in Kenya such that an increase in a return on average assets leads to a decreases in NPLs among commercial banks in Kenya and a decrease in ROA leads to an increase in non-performing loans among commercial banks in Kenya. Thus, the profitability of the Kenyan CBs, in terms of ROA, influences the level of NPLs. ROA, in the banking institutions, an important indicator that captures the movements of assets including loans and advances the growth of has implications on NPLs, High quality of management of ROA leads to a low level of NPLs. The higher profitability (ROA), the less the income generated, which make the bank relax in their resolve to grant risky loans. A reduction in the quality banks' assets implies that the banks are not able to generate income. High ROA is an indication that the banks are effective in disbursement and collection and are also careful in lending and collecting the disbursed funds.

\subsection{Study Limitations}

This study was limited in some ways. Firstly, accessing the proposed financial records form the prospective sources directly might have been a lengthy process that might have significantly delayed the time of the study. So avoid this limitation, the study, in addition to obtaining data from the proposed sources also retrieved source data from online databases. The study tested the problem of multicollinearity between independent variables, which means that some variables might have been dropped from the study to avoid the problem of multicollinearity. However, every effort however, was made so as to lessen the effect of the expected limitation on the credibility of the results of the study.

\subsection{Recommendations}

The study suggested policy recommendation and recommendation for further study. This is because NPLs must be minimized until it would no longer be a threat to the economic growth of the country (Mondal, 2016).

\subsubsection{Recommendations on Research Findings}

The following policy recommendation was made based on the reproach findings. First, the study recommends that the Central Bank of Kenya (CBK) should set up strategy for controlling interest rate spread as the Government of Kenya in controlling the interest rate. The Central Bank of Kenya should provide guidelines for setting a threshold for IRS, minimizing it to the best optimum levels. There should be a standard for determining new interest rate ensuring that new interest rates do not hurt the banking sector and the favor the customers as well. As a way of protecting the widening margins of IRS, the commercial banks in Kenya should adequately assess the market expectations before releasing new products. They must have sufficient knowledge of the market demands, which will guide them in determining favorable interest rates in line with the existing interest rates. Accordingly, the banks should be careful when developing and releasing riskier products despite such products appearing conducive to the prospective consumers. There should be adequate research on the product to ascertain the impact it would have on the IRS and importantly on the NPLs

Secondly, the study established that there are increasing levels of operating efficiency amongst Kenyan CBs, which must be checked since they highly accelerate the growth of NPLs amongst these banks. This confirms the rationale of having cash ratio so that you cannot go beyond a certain ratio. Accordingly, the present study recommends that the CBK should set guidelines of the maximum percentage of operating efficiency, by setting the threshold operating efficiency ratio. This should be coupled with; adequacy in strict loan monitoring and recovery, effective bank loaning policies (Abdeta, 2015; Amoako, 2015)

Thirdly, the study established that lowering the liquidity ratio (quality of assets) increase the levels of NPLs. A reduction in the quality of banks' assets (liquidity ratio) implies that the banks are not able to generate income. There is therefore the need to overcome this limitation which is occasioned by the increasing decrease of the liquidity ratio that lowers the quality of banks' assets.

Lastly, the study recommends that the banking institutions in Kenya should seek to enhance their ROA, by ensuring that the movements of assets including loans and advances grow with time, the Kenyan commercial banks ensure that they manage their ROA through quality management for the purpose of reducing the level of NPLs. These banks should implement strategies geared towards higher profitability (ROA), which would make the bank to relax in their resolve to granting risky loans. High ROA is an indication that the banks are effective in disbursement and collection and are also careful in lending and collecting 
the disbursed funds (Sheefeni, 2015).

\subsubsection{Recommendations for Further Study}

Other suggested studies include:

1. The study established that the average level of non-performing loans among Kenyan commercial banks was $8.18 \%$ which was higher than the threshold of $5 \%$ as suggested by the CBK's prudential guidelines. Notably, there was a $45.3 \%$ increase of NPLs as of December 2016 as compared to December 2015. So, other studied are required to establish the reasons for the surge in the level of non-performing loans in Kenyan commercial banks

2. The present study established that there are concerns of the high margins of IRS, which highly contribute towards the growth of NPLs in Kenyan commercial banks. The present study was not able to establish the optimum (highest) admissible percent of IRS that would not significantly impact of the NPLs. Therefore, the present study proposes that other studies should be conducted to establish the threshold point of IRS that should not be exceeded for the growth of NPLs to be avoided and hence mitigate any possible financial crisis in the commercial banking sector.

3. The study found that the operating efficiency was very high amongst the Kenyan commercial banks and when operating efficiency is very high it indicates that the banks are lending almost everything at their disposal, which is very risky, a further study should be conducted for establishing the optimal ratio of operating efficiency to be maintained by commercial banks in Kenya for avoidance of growth in NPLs amongst these banks.

4. The study established that $31.38 \% \%$ of variation in non-performing loans among commercial banks in Kenya is explained by change in; interest rate spread, operating efficiency, liquidity ratio, and return on average assets. So another study should be conducted to establish the factors influencing the remaining $68.62 \%$ of variation in non-performing loans among commercial banks in Kenya

\section{REFERENCES}

[1] Abdeta, M. (2015). Determinants of nonperforming loan in development bank of Ethiopia (Master's Thesis, St. Mary's University, and Addis Ababa, Ethiopia).

[2] Ahlem, S. M. \& Fathi, J. (2013). Micro and micro determinants of nonperforming; Tunisia. International Journal of Economics and Financial Issues. 3(4), 852-860.

[3] Amoako, K. A. (2015). The effect of bad loans on the profitability and lending potential of rural banks. A case study of some selected rural banks in the Ashanti region
(Master’s Thesis, Kwame Nkrumah University of Science and Technology, Kumasi, Ghana).

[4] Asfaw, A. S., Bogale, H. N. B. \& Teame, T. T. (2016). Factors affecting non-performing loans. Case study of Development Bank of Ethiopia, Central Region. International Journal of Scientific and Research Publications, 6(5), 656 - 670. Retrieved from www.ijsrp.org

[5] Asmare. A. (2014). Determinants of banks interest rate spread: an empirical evidence from Ethiopian commercial banks (Master's thesis, University Addis Ababa, Addis Ababa, Ethiopia).

[6] Atem, N. M. C. (2017). Factors affecting non-performing loans: A case study of KCB Bank Kenya Limited Nairobi Region (Masters Research Project, Catholic University of Eastern Africa, Nairobi, Kenya).

[7] Athanasoglou, P. P. Sophocles, N. B. \& Matthaios, D. D. (2005) Bank-specific, industry-specific and macroeconomic determinants of bank profitability. Working paper, Bank of Greece. 1(1), 3-4.

[8] Auronen, L. (2003), Asymmetric information: Theory and applications. Paper presented in the Seminar of Strategy and International Business as Helsinki University of Technology, May 21st 2003.

[9] Bester, H (1994). The role of collateral in a model of debt renegotiation. Journal of Money, Credit and Banking, 26 (1), 72-86.

[10] Buchory, H. A. (2015). Banking intermediation, operational efficiency and credit risk in the banking profitability. International Journal of Business, Economics and Law, $7(2), 57-63$

[11] Central Bank of Kenya [CBK] (2016a). Commercial Banks. Retrieved from https://www.centralbank.go.ke/commercial -banks/

[12] Central Bank of Kenya [CBK] (2016b). Banking supervision Report 2016. Nairobi: CBK

[13] Chege, L. M. \& Bichanga, J. (2017). Non-performing loans and financial performance of banks: An empirical study of commercial banks in Kenya. International Journal of Management and Commerce Innovations, 4(2), 909-916.

[14] Chimkono, E. E., Muturi, W. \& Njeru, A. (2016). Effect of non-performing loans and other factors on performance of commercial banks in Malawi. International Journal of Economics, Commerce and Management, IV (2), 549 - 563.

[15] Chodechai, S. (2004), Determinants of bank lending in Thailand: An empirical examination for the years 1992 1996 (Master Thesis).

[16] Cucinelli, D. (2015). The Impact of non-performing loans on bank lending behavior: evidence from the Italian Banking Sector. Eurasian Journal of Business and Economics, 8(16), 59-71.

[17] Duraj, B \& Moci, E (2015). Factors influencing the bank profitability - Empirical from Albania. Asian Economic and Financial Review, 5(3), 483-494

[18] Ekanayake, E. M. N. N. \& Azeez, A. A. (2015). 
Determinants of non-performing loans in licensed commercial banks: Evidence from Sri Lanka. Asian Economic and Financial Review, 5(6), 868- 882.

[19] Fawad, A. \& Taqadus, B (2013). Explanatory power of macroeconomic variables as determinants of non-performing loans: Evidence Form Pakistan. World Applied Sciences Journal, 22(2).

[20] Frederick, N. K. (2014). Factors Affecting performance of commercial banks in Uganda. A case for Domestic Commercial Banks. Proceedings of 25th International Business Research Conference, Taj Hotel, Cape Town, South Africa.

[21] Gathaiya, R. N. (2017). Analysis of Issues Affecting Collapsed Banks in Kenya From Year 2015 to 2016. International Journal of Management \& Business Studies (IJMBS), 7(3), 9-15

[22] Genga, B. (2016). Chase Bank Kenya Executives Resign After Earnings Restated. Business Daily.

[23] Gezu, G. (2014). Determinants of nonperforming loans: Empirical study in case of commercial banks in Ethiopia (Master's thesis, Jimma University, Jimma, Ethiopia).

[24] Ghasemi, A. \& Rostami, M. (2016). Determinants of interest rate spread in banking industry. Ecoforum, 5(1), 320-331.

[25] Gupta, S. K. \& Rangi, R. (2014). Research methodology. Methods, tools and techniques ( $4^{\text {th }}$ Ed.). New Delhi: Kalyan Publishers.

[26] Hassan, H. I. lyas, M. \& Rehman, C. A. (2015). Quantitative study on bank specific and social factors on non-performing loans in Pakistan Banking Sector. International Letters of Social and Humaities, 43, 192 - 203.

[27] Hue, N. T. M. (2015). Non-performing loans affecting factors of sustainability of Vietnam Commercial Banks. Journal of Economic and Development, 17(1), 93 - 106.

[28] Iftikhar, S. F (2015). Financial reforms and financial fragility: A panel data analysis. International Journal of Financial

Studies, 3, 84-101. Retrieved from www.mdpi.com/journal /ijfs.

[29] Irungu, P. (2013). The effect of interest rate spread on financial performance of commercial banks in Kenya. Nairobi, Kenya.

[30] Islam, S. \& Nishiyama, S-I. (2016). The determinants of non-performing loans: dynamic panel evidence from South Asian countries. Sendai, Japan: Tohoku Economics Research Group

[31] Kanu, C. \& Isu, H. O. (2014). The rising incidence of non -performing loans and the nexus of economic performance in Nigeria: An investigation. European Journal of Accounting Auditing and Finance Research, 2(5), 87-96

[32] Karim, M. Z. A., Chan S. G, \& Hassan, S. (2010). Bank efficiency and non-performing loans: Evidence from Malaysia and Singapore Prague. Economic Papers, 2(2010)

[33] Karumba \& Wafula (2012). Collateral lending: Are there alternatives for the Kenyan banking industry? Nairobi: Kenya Bankers Association.
[34] Klein, N. (2013). Non-Performing Loans in CESEE: Determinants and Impact on Macroeconomic Performance/ IMF Working Paper, WP/13/72.

[35] Kothari, C. R. (2012). Research methodology: Methods and techniques. Reprint. New Delhi: New Age International (P) Ltd.

[36] Kristianti, R. A. \& Yovin. (2016). Factors affecting bank performance: cases of top 10 biggest government and private banks in Indonesia in 2004 - 2013, Review of Integrative Business Econonics Research, 5(4), 371-378. Retrieved from http://buscompress.com/journal-home.html.

[37] Lavrakas, P. (2008), Survey Research Methods.

[38] Mabvure, J. T., Edson, G., Manuere, F., Clifford, M., \& Michael, K. (2012). Non-performing loans in Commercial Banks: A case of CBZ Bank Limited in Zimbabwe. Interdisciplinary Journal of Contemporary Research in Business, 7, 467-488.

[39] Malimi, K. (2017). The influence of capital adequacy, profitability, and loan growth on non-performing loans a case of Tanzanian Banking Sector. International Journal of Economics, Business and Management Studies, 4(1), 38-49

[40] Messai, A., S, \& Jouini, F. (2013). Micro and macro determinants of non-performing loans. International Journal of Economics and Financial Issues, 3(4), 852- 860.

[41] Mingaleva, Z., Zhumabayeva M., Karimbayeva G. (2014). The reasons of non-performing loans and perspectives of economic growth. Life Science Journal, 11(5s), 157 - 161.

[42] Mitku, M. (2014). Determinants of commercial banks' lending: Evidence from Ethiopian Commercial Banks. European Journal of Business and Management, 6.

[43] Mondal, T. (2016). Sensitivity of non-performing loan to macroeconomic variables: Empirical evidence from banking industry of Bangladesh. Global Journal of Management and Business Research: CFinance, 16(4), 21 28. Retrieved from http://creativecommons.org/licenses/by-nc/3.0/

[44] Muchoki, C. N. \& Were, S. (2016). Effect of Response Strategies on the Performance of Commercial Banks in Kenya. International Journal of Social Sciences Management and Entrepreneurship, 3(2), 173 - 192.

[45] Mudzingwa, N. B. (2013). Determinants of interest rate spreads in Zimbabwe (Bachelors Dissertation, Midlands State University).

[46] Mugenda, O. M. \& Mugenda, A. G. (2008) Research methods: Quantitative and qualitative approaches. Nairobi Kenya: ACTS

[47] Muriithi, M. W. (2013). The causes of non-performing loans in commercial banks in Kenya (Masters Project, University of Nairobi, Nairobi, Kenya).

[48] Musau. E. M (2014). Modeling non-performing loans in Kenya commercial banks (Master's thesis, University of Nairobi, Nairobi, Kenya).

[49] Navaretti, G. B., Calzolari,G. \& Pozzolo, A. F. (2017). Non-Performing loans. Getting rid of NPLs in Europe. European Economy. Retrieved from www.european-economy.eu. 
[50] Ongore, V. O. \& Kusa, G. B. (2013). Determinants of financial performance of commercial banks in Kenya. International Journal of Economics and Financial Issues, 3(1), 237-252.

[51] Petria, N; Capraru, B \& Ihnatov, I. (2015. Determinants of banks' profitability: Evidence from EU 27 Banking Systems. Procedia Economics and Finance Elsevier, 20, $518-524$.

[52] Sheefeni, J. P. S. (2015). Evaluating the impact of bank specific determinants of non-performing loans in Namibia. Journal of Emerging Issues in Economics, Finance and Banking (JEIEFB), 4(2), 1525 - 1541.

[53] Sheefeni, J. P. S. (2016). The effects of interest rate spread on non-performing loans in Namibia. European Journal of Business, Economics and Accountancy, 4(5), 31- 40.

[54] Shingjergji, A. (2013). The Impact of bank specific variables on the non-performing loans ratio in the Albanian banking system. Research Journal of Finance and Accounting, 4(7), 148-152.

[55] Swamy, V. (2012): Impact of macroeconomic and endogenous factors on nonperforming bank assets. International Journal of Banking and Finance, 9.

[56] Tesfai, A., 2015. Evaluating the relationship between liquidity, capital adequacy and non-performing loans on financial performance: Case study of Habib Bank AG Zurich (Master Thesis, United States International University, Nairobi, Kenya).

[57] Vasiliki, M. Athanasios, T. \& Athanasios, B. (2014): Determinants of nonperforming loans: The Case of Eurozone. Panoeconomicus, 2, 193-206.

[58] Vatansever, M. \& Hepsen, A. (2013). Determining impacts on non-performing loan ratio in Turkey. Journal of Finance and Investment Analysis, 2(4), 119-129.

[59] Warue, B. N. (2013). The effects of bank specific and Macroeconomic factors on non-performing loans in commercial banks in Kenya. A comparative panel data analysis. Advances in Management \& Applies economics, 3(2), 135 - 164 